\title{
STUDY OF DNA REPAIR OF THE FIBROBLASTS FROM PATIENTS WITH SYSTEMIC LUPUS ERYTHEMATOSUS
}

\author{
Akihide Ohta, Fumitaka Morrto, and Masaya Yamaguchi \\ Division of Rheumatology and Allergy, Department of Internal Medicine, \\ Saga Medical School, Nabeshima, Saga 840-01, Japan
}

\begin{abstract}
Summary An ability of the fibroblasts to repair ultraviolet (UV)-induced damage of DNA was investigated in patients with systemic lupus erythematosus (SLE). Unscheduled DNA synthesis (UDS) and survival rate in SLE fibroblasts were not reduced in comparison with those in normal fibroblasts, as Cleaver had reported previously (1970). In addition, sera from SLE patients had no effects on UDS. In the fibroblast colony studies, some clones exhibited decreased UDS, though mean UDS of all colonies was approximately same among different individuals. This intra-individual clonal variation in UDS occurred in both SLE patients and controls. These results indicate that the capacity of DNA repair of the fibroblasts from SLE patients is at the same level as those from normal individuals. In SLE patients, however, such cione(s) of cells with decreased level of DNA repair may present the damaged DNA induced by UV light as antigen, which will form the immune complexes under an abnormal immune responsiveness, leading to the development of photosensitivity.
\end{abstract}

\section{INTRODUCTION}

Photosensitivity is one of the important clinical symptoms of the patients with systemic lupus erythematosus (SLE), but the mechanism by which sunlight induces skin lesions and exacerbates disease activity is not clearly defined.

Tan and Stoughton (1969) demonstrated that ultraviolet (UV) light irradiation of mice could produce in vivo conversion of native DNA to UV-denatured DNA (UV-DNA) which was known to be a potent immunogen (Levine et al., 1966). They suggested that this could be the mechanism of photosensitive induction of disease activity and exacerbation in cases of SLE. Cripps and Rankin (1973) found the immune deposition at the dermal-epidermal junction several weeks after exposure

Received June 23, 1986; revised version received August 11, 1986; Accepted October 6, 1986 
of skin of the patients with disseminated discoid lupus erythematosus to UV light of wavelength of 250-313 nm. Davis (1977) demonstrated that antibodies to UVDNA were detectable in sera of SLE patients but not in sera of the patients with other photodermatoses. So they implicated the possibility of the defect to DNA repair mechanism in SLE patients.

Beighlie and Teplitz (1975) showed that lymphocytes from SLE patients had a defect in repair mechanism of UV-damaged DNA especially in excision step analogous to the pathogenic mechanism of xeroderma pigmentosum (XP, Cleaver, 1968), and that this lack of repair might be at least one of the etiologic factors involved in SLE. Several other reports have indicated reduced rapair capacity in the bone marrow cells (Altmann and Eberl, 1971) and peripheral lymphocytes (Eberl et al., 1973; Nienhold and Legator, 1976) of the patients with SLE. However, opposite findings have been reported by other investigators: unscheduled DNA synthesis (UDS) of fibroblasts (Cleaver, 1970) or lymphocytes (Horkay et al., 1975) from SLE patients was approximately at the same level as that of normal cells. Thus, there has been controversy concerning DNA repair in patients with SLE. In an attempt to further clarify the DNA repair capacity in SLE patients, we examined UDS and survival rate of UV-irradiated fibroblasts. In addition, clonal variation of UDS and effects of sera from SLE patients on DNA repair were studied.

\section{MATERIALS AND METHODS}

Cell preparation. Fibroblast cultures were established from biopsies of the skin in apparently normal arm regions of eight patients with SLE. These patients were all female, aged 18 to 43 . All of them conformed to the criteria for SLE by the American Rheumatism Association (1971), and never received any drugs which had been known to affect DNA repair. Normal fibroblasts from four healthy females, aged 16 to 42 and fibroblasts from a 4-year-old boy patient with XP were also cultured by the same methods. Cells were grown in Dulbecco's modified Eagle's medium (D-MEM, GIBCO, N.Y.) supplemented with $20 \%$ fetal calf serum (FCS, Granite Diagnostis Inc., N.C.), $100 \mathrm{u} / \mathrm{ml}$ penicillin and $50 \mu \mathrm{g} / \mathrm{ml}$ gentamycin in humidified atmosphere of $5 \% \mathrm{CO}_{2}$ in air at $37^{\circ} \mathrm{C}$. Fibroblasts between 4 and 10 passages were used for all experiments.

Estimation of UV-induced unscheduled DNA synthesis (UDS). Fibroblasts were inoculated to each well of the slide chamber (Bellco Glass Inc., N.J.) (5,000 cells/ $0.1 \mathrm{ml} /$ each well) and incubated at $37^{\circ} \mathrm{C}$ for $18 \mathrm{hr}$. Then after UV-irradiation using short wave UV lamp (Model UVS-54, Ultraviolet Products Inc., Calif.) at an incident dose rate of $1.2 \mathrm{~J} / \mathrm{m}^{2} / \mathrm{sec}$ monitored by a $\mathrm{J}-225$ short wave meter (Ultraviolet Products Inc.), cells were incubated with medium containing $10 \mu \mathrm{Ci} / \mathrm{ml}$ of ${ }^{3} \mathrm{H}$-thymidine ( ${ }^{3} \mathrm{H}-\mathrm{TdR}, 54 \mathrm{Ci} / \mathrm{mmol}$, Amersham International Ltd., England) for $3 \mathrm{hr}$ and were processed for autoradiography as described previously (Cleaver, 1969). In autoradiographic preparations, grains on "lightly labeled" nuclei (less than 200 
grains per nucleus) were counted, and the average number of grains per nucleus was calculated in 100 nuclei. The background which was determined by counting the number of grains in 10 fields equal in size to a cell nucleus was subtracted from former grain numbers.

Cell survival studies. Appropriate dilutions of the fibroblasts from five SLE patients, four normal individuals and one XP patient were plated in $5 \mathrm{ml}$ of D-MEM in $60 \mathrm{~mm}$ petri dishes. Approximately $18 \mathrm{hr}$ later, the medium was removed and the cells were irradiated with UV light at various doses. Then the cells were reincubated for 10 days, at which time they were fixed with methanol and stained. Colonies containing more than 50 cells were scored as survivors. Each experiment was done in triplicates at each UV dose.

Evaluation of the effects of sera from SLE patients on UDS. Sera from three SLE patients and from a normal individual with blood group $A B$ who had never received blood transfusion were separated and complement-inactivated. Fibroblasts from three SLE patients were incubated in D-MEM containing $20 \%$ autologous serum or normal human serum instead of FCS for $3 \mathrm{hr}$ before UV irradiation and for $3 \mathrm{hr}$ thereafter. They were labeled with ${ }^{3} \mathrm{H}-\mathrm{TdR}$ for $3 \mathrm{hr}$ after UV irradiation and were processed for autoradiography. In addition, fibroblasts from three normal individuals were incubated similarly with serum from one of SLE patients or normal human serum. Then UDS was examined as described above.

Study of UDS in intra-individual fibroblast colonies. Fibroblasts were incubated on the sterilized slide glass which was placed in the $100 \mathrm{~mm}$ petri dish ( 100 cells/0.1 $\mathrm{ml} / \mathrm{each}$ glass). One or two hours later when cells had been attached to the slide glass, $15 \mathrm{ml}$ of medium was added and the cells were incubated for about 10 days. When several colonies containing about 50-100 cells grew while they were still clearly distinguishable from one another, they were irradiated with UV light and UDS of the fibroblasts from each colony was examined autoradiographycally as described above.

\section{RESULTS}

\section{Estimation of unscheduled DNA synthesis}

Mean grain numbers of the fibroblasts from SLE patients and controls after UV irradiation at various doses are shown in Table 1. With increase in UV dose UDS increased in the fibroblasts from SLE patients as well as those from normal individuals. There were no significant differences $(p>0.1)$ in UDS between these two groups at each UV dose. On the contrary, the fibroblasts from XP patient showed no increase in UDS as UV dose increased, indicating almost complete absence of DNA repair.

\section{Cell survival studies}

As seen in Fig. 1, survival rate of the fibroblasts from SLE patients after UV irradiation was approximately at the same level as that from the normal fibroblasts, 
Table 1. Mean grain numbers in autoradiographs of SLE and control fibroblasts after UV irradiation at various doses.

\begin{tabular}{lcrrrrr}
\hline Subjects & $\begin{array}{c}\text { Number } \\
\text { of } \\
\text { patients }\end{array}$ & UV(-) & $4.5 \mathrm{~J} / \mathrm{m}^{2}$ & $9.0 \mathrm{~J} / \mathrm{m}^{2}$ & $18.0 \mathrm{~J} / \mathrm{m}^{2}$ & $32.0 \mathrm{~J} / \mathrm{m}^{2}$ \\
\hline SLE & 8 & $0.7 \pm 3.9$ & $26.5 \pm 11.9$ & $30.3 \pm 11.9$ & $100.5 \pm 31.0$ & $129.0 \pm 32.8$ \\
Normal individual & 4 & $0.4 \pm 1.8$ & $28.6 \pm 12.2$ & $44.5 \pm 17.5$ & $111.6 \pm 33.7$ & $139.5 \pm 30.5$ \\
XP & 1 & $0.1 \pm 1.4$ & $1.4 \pm 3.6$ & $1.2 \pm 4.5$ & $1.0 \pm 3.8$ & $1.3 \pm 2.9$ \\
\hline
\end{tabular}

No statistically significant differences were seen in grain numbers between SLE and normal fibroblasts using Student's $t$-test at $\mathrm{p}<0.10$, contrary to the statistical significance at $\mathrm{p}<0.001$ in comparison of $\mathrm{XP}$ fibroblasts with other two cell groups.

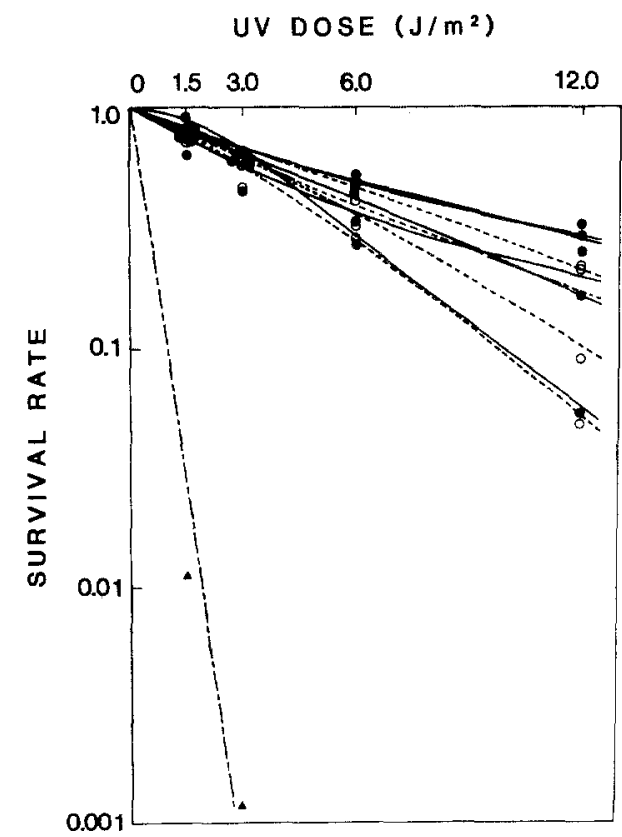

Fig. 1. Survival rate of UV irradiated fibroblasts. The survival rate was calculated as the number of surviving cells divided by the product of the number of cells plated and the plating efficiency. Each experimental value represents an average of triplicates. SLE; $\bigcirc$, normal individual; $\wedge$, XP.

while it remained severely low in XP cells. The $D_{0}$ values (dose necessary to reduce survival rate to $37 \%$ on the linear portion of the curve) were in the range of 3.6-10.5 $(7.4 \pm 2.5$, mean \pm S.D. $) \mathrm{J} / \mathrm{m}^{2}$ in the cells from SLE patients and 3.8-7.6 (5.9 \pm 2.0$)$ $\mathrm{J} / \mathrm{m}^{2}$ in normal cells, showing no significant differences $(\mathrm{p}>0.3)$.

Effects of sera from SLE patients on UDS

Though the data described above indicated that DNA repair capacity of the fibroblasts from SLE patients was not decreased, there might be some factors influ- 
Table 2. Effect of serum from SLE patients on UV induced unscheduled DNA synthesis.

\begin{tabular}{|c|c|c|c|}
\hline Subjects & Number & $\begin{array}{l}\text { Grain number } \\
\text { (mean }+ \text { S.D.) }\end{array}$ & Student's $t$-test \\
\hline \multicolumn{4}{|l|}{ SLE fibroblasts with } \\
\hline SLE serum (autologous) & 3 & $141.7 \pm 23.4$ & \multirow{3}{*}{$\begin{array}{c}\text { N.S. }{ }^{2}(p>0.2) \\
0.1<p<0.2\end{array}$} \\
\hline Normal human serumb & 3 & $129.0 \pm 30.4$ & \\
\hline Fetal calf serum & 3 & $90.4 \pm 26.2$ & \\
\hline \multicolumn{4}{|l|}{ Normal fibroblasts with } \\
\hline SLE serum ${ }^{\mathrm{c}}$ & 3 & $139.2 \pm 27.0$ & \multirow{3}{*}{$\begin{array}{c}\text { N.S. }(p>0.5) \\
0.1<p<0.2\end{array}$} \\
\hline Normal human serum (not autologous) & 3 & $137.7 \pm 27.5$ & \\
\hline Fetal calf serum & 3 & $113.4 \pm 31.3$ & \\
\hline
\end{tabular}

Data are shown of the cases after UV irradiation at dose of $18.0 \mathrm{~J} / \mathrm{m}^{2}$. ${ }^{\mathrm{a}} \mathrm{N} . \mathrm{S}$, not significant. b Normal human serum was obtained from an individual with blood group $A B$ who had not received blood transfusion. ${ }^{c}$ In the experiment of the effect of SLE serum on UDS of normal fibroblasts, serum used was obtained from one of SLE patients who were examined for autologous serum effect.

encing the expression of DNA repair of the fibroblasts in vivo. Therefore we studied an effect of sera from SLE patients on DNA repair. As shown in Table 2, UDS of the fibroblasts from SLE patients in the presence of autologous serum was not significantly different ( $p>0.2$ ) from those in the presence of normal human serum, though both cultures with human serum showed somewhat higher level of UDS than those with FCS $(0.1<p<0.2)$. In addition, serum from SLE patients had no effect on UDS of normal fibroblasts $(p>0.5)$.

\section{Comparison of UDS among fibrohlast colonies}

To learn if there are some fibroblast clones showing decreased level of DNA repair, we investigated UDS of each colony of the fibroblasts from SLE patients. Mean grain numbers over nuclei of each fibroblast colony are shown in Fig. 2. As to the total mean grain numbers calculated from all colonies per each individual, there were no significant differences $(p>0.2)$ between SLE patient (SLE III) and control (normal control IV). However, there were some fibroblast clones showing decreased mean grain numbers. This reduction equally occurred in the fibroblast clones from SLE patient and from normal individual. In the case of SLE III, mean grain number of colony 1 was significantly smaller than that of colony $3(p<0.001)$. Similarly, in the case of normal control IV, mean grain number of colony 2 was significantly decreased in comparison with colony $I$ and colony $3(p<0.001)$. These data might implicate intra-individual clonal variation of UDS which equally exists in SLE patients and normal individuals. 


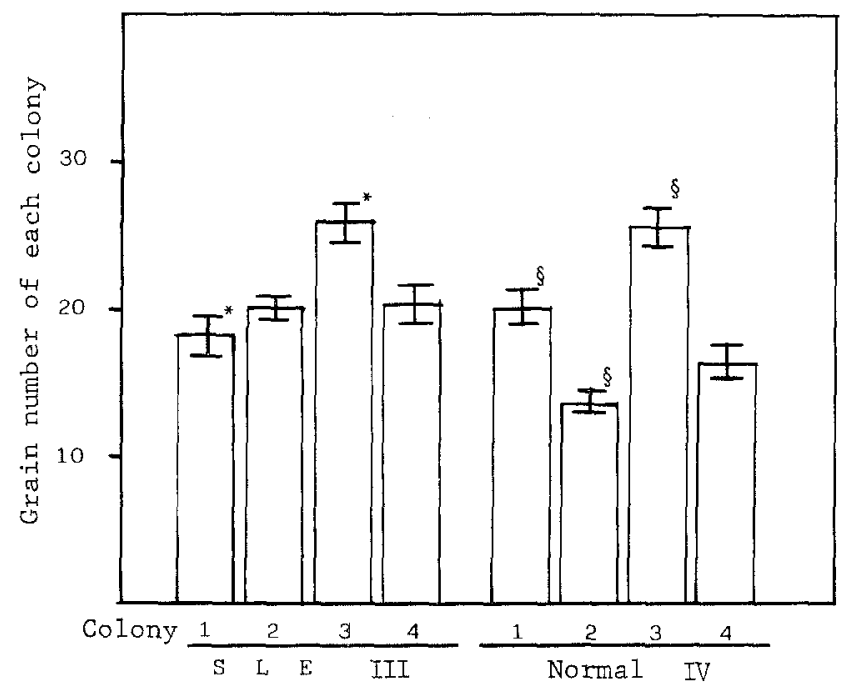

Fig. 2. Comparison of grain numbers among fibroblast colonies. Data shown were obtained from the cases after UV irradiation at dose of $3.0 \mathrm{~J} / \mathrm{m}^{2}$. Each grain number was expressed as mean - S.E.M. Total mean grain number which was calculated from all colonies per each individual was $21.2 \pm 1.3$ in SLE III and $18.9+1.3$ in normal control IV, showing no statistical significance $(p>0.2)$. *In the case of SLE III, difference was significant in mean grain number between colony 1 and colony 3 ( $\mathrm{p}<0.001$, according to Student's $t$-test). $\S$ In the case of normal individual IV, mean grain number of colony 2 was significantly smaller than that of colony 1 or colony $3(\mathrm{p}<0.001)$.

\section{DISCUSSION}

The results of the present study indicate that neither excision repairs, nor overall capacity of DNA repairs in fibroblasts of the patients with SLE is decreased as compared with those of normal individuals. Reduced DNA repair synthesis in lymphocytes from SLE patients has been reported by Beighlie and Teplitz (1975), Eberl et al. (1973), and Nienhold et al. (1976). In their studies, however, comparison has been made on the total population of the lymphocytes, but not on the subpopulations which may differ in the repair capacities. In fact, abnormal composition of lymphocyte subpopulations is known to exist in SLE patients (Messner et al., 1973). Moreover, Giannelli (1980) indicated that the use of lymphocytes for analysis of DNA repair synthesis is inappropriate in the case of abnormal immune responses as in SLE patients. Thus, there seem to be some difficilties in using lymphocytes for the comparison of DNA repair synthesis between SLE patients and normal controls.

Some chemical agents such as caffeine (Apfelzweig and Teplitz, 1979; Cleaver, 1981) and chloroquine (Gaudin et al., 1971) affect DNA repair directly, inhibiting certain process of DNA repair. So there might be some extracellular factors mod- 
ulating the expression of DNA repair of the fibroblasts from SLE patients in vivo. Therefore we examined the effects of serum on UDS of the fibroblasts in vitro. In the present study, sera from SLE patients had no significant effect on UDS of the fibroblasts from patients as compared with those from normal controls.

The clonal study on UDS revealed that some of fibroblast clones have a decreased capacity of UDS both in the patient with SLE and control. These fibroblast clones with reduced level of UDS seem to exist equally both in patients and normal individuals, since total mean grain numbers which were thought to represent mean UDS of each individual were almost same among them. There have been several reports that terminally differentiated cells such as neurons, muscle cells (Lieberman and Forbes, 1973) and granulocytes (Pero et al., 1978; Connor and Norman, 1971; Ringborg and Lambert, 1977) have reduced UDS capacity associated with their lack of replicative DNA synthesis. These variations in UDS observed among tissues and also among fibroblast clones as described above lead to an idea that there might be considerable diversity of the capacity of DNA repair in cells of an individual.

In SLE patients, antigenic denatured DNA could be produced with exposure of sunlight at the same degree as in normal individuals due to existence of fibroblast clones with decreased capacity of DNA repair. However, underlying immunological hyperresponsiveness against various antigenic stimuli, which is considered to be essentially pathogenic in SLE rather than the defective DNA repair system, might result in the production of antibodies against the damaged DNA more easily and excessively in patients than in normal individuals. Thus, excessively produced anti UV-DNA antibodies, with repeated sun exposures, might result in the formation and deposition of immune complexes in patient's skin, leading to the development of photosensitivity and/or photo-induced exacerbation in SLE.

\section{REFERENCES}

Altmann, H. and Eberl, R. 1971. Untersuchungen über die DNS-Reparationskapazität von Knochenmarkzellen bei Lupus erythematodes. Wiss. Ztschr. Friedlich-Schiller-Univ. 20: $477-480$.

Apfelzweig, R.A. and Leplitz, R.L. 1979. A study of the effect of caffeine upon excision repair of damaged DNA. Mutation Res. 62: 151-158.

Beighlie, D.J. and Teplitz, R.L. 1975. Repair of UV damaged DNA in systemic lupus erythematosus. J. Rheumatol. $2: 149-160$.

Cleaver, J.E. 1968. Defective repair replication of DNA in xeroderma pigmentosum. Nature 218: $652-656$.

Cleaver, J.E. 1969. Xeroderma pigmentosum: A human disease in which an initial stage of DNA repair is defective. Proc. Natl. Acad. Sci. U.S.A. 63: 428-435.

Cleaver, J.E. 1979. DNA damage and repair in light-sensitive human skin disease. J. Invest. Dermatol. 54: 181-195.

Cleaver, J.E. 1981. Inhibition of DNA replication by hydroxyurea and caffeine in an ultravioletirradiated human fibroblast cell line. Mutation Res. 82: 159-171.

Connor, W.G. and Norman, A. 1971. Unscheduled DNA synthesis in human leucocytes. Mutation Res. 13: 393-402. 
Cripps, D.J. and Rankin, J. 1973. Action spestra of lupus erythematosus and experimental immunofluorescence. Arch. Dermatol. 107: 563-567.

Davis, P. 1977. Antibodies to UV DNA and photosensitivity. Br. J. Dermatol. 97: 197-200.

Eberl, R., Tuschl, H., and Altmann, H. 1973. Über die Rolle der DNS-Reparaturen bei gewissen rheumatischen Erkrankungen. Wien. Klin. Wschr. 85: 315-318.

Gaudin, D., Yielding, K.L., Stabler, A., and Brown, J. 1971. The effect of DNA repair inhibitors on the response of tumors treated with X-ray and alkylating agents. Proc. Soc. Exp. Biol. Med. 137: 202-206.

Giannelli, F. 1980. DNA repair in human diseases. Clin. Exp. Dermatol. 5: 119-138.

Horkay, I., Nagy, E., Tamasi, P., Szabo, M., and Csongor, J. 1975. DNA repair and UV-light sensitivity of the lymphocytes in discoid lupus erythematosus. Studia Biophys. Berlin. Band 50: S.1-6.

Levine, L., Seaman, E., Hammerschlag, E., and Vunakis, H. 1966. Antibodies to photoproducts of deoxyribonucleic acids irradiated with ultraviolet light. Science 153: 1666-1667.

Lieberman, M.W. and Forbes, P.D. 1973. Demonstration of DNA repair in normal and neoplastic tissues after treatment with proximate chemical carcinogens and ultraviolet radiation. Nature New Biol. 241: 199-201.

Messner, R.P., Lindström, F.D., and Williams, R.C. 1973. Peripheral blood lymphocyte cell surface markers during the cource of systemic lupus erythematosus. J. Clin. Invest. 52: 30463056.

Nienhold, I. and Legator, M.S. 1976. Inhibition of DNA repair synthesis in cells derived from patients with systemic lupus erythematosus after exposure to 4-nitroquinoline-1-oxide. V. International Congress of Human Genetics, October 10-15, Mexicc City.

Pero, R.W., Bryngelsson, C., Mitelman, F., Kornfalt, R., Thulin, T., and Norden, A. $1978 . \quad$ Interindividual variation in the responses of cultured human lymphocytes to exposure from DNA damaging chemical agents, interindividual variation to carcinogen exposure. Mutation Res. 53: $327-341$.

Ringborg, U. and Lambert, B. 1977. Ultraviolet-induced DNA repair synthesis in lymphocytes from patients with chronic lymphatic leukemia. Cancer Lett. 3: 77-81.

Tan, E.M. and Stoughton, R.B. 1969. Ultraviolet light alteration of cellular deoxyribonucleic acid in vivo. Proc. Natl. Acad. Sci. U.S.A. 62: 708-714. 